is so characteristic that it sufficed, without any other aids to diagnosis, for the exact localization of the tumour in a series of 24 patients, all of which cases were verified surgically.

M. Hamblin Smith.

A Case of Narcoleptic Cataplexy, Probably of Encephalitic Origin [Cataplexia narcoléptica, provávelmente encefalitica]. (Rev. da Assoc. Paulista de Med., vol. iii, p. 183, Oct., 1933.) Vampré, E., Sobrinho, P., and Ribeiro, J.

Observations upon narcoleptic cataplexy are rare. The authors give a detailed description of a case. They believe that the phenomena presented by the disease depend upon a larval type of epidemic encephalitis. The syndrome consists of a repetition of crises manifested by a general or localized loss of positional tone and of muscular power. It is never easy to eliminate entirely the possibility of simulation.

M. Hamblin Smith.

\title{
5. Treatment.
}

Mechanism of the Action of Calcium and Potassium Salts Injected into the Cerebral Ventricles. (Compt. Rend. Soc. Biol., vol. cxiv, p. 674, 1933.) Stern, L., Rossine, J. A., and Chroles, G. J.

The direct action of calcium on the vegetative nervous centres of the brain consists of an excitation of the parasympathetic centres (vaso-dilator and cardiac inhibitor), but a possible inhibitor effect on the sympathetic centres is not excluded. Potassium excites the vaso-constrictor and cardiac centres and probably indirectly weakens the tonus of the parasympathetic centres

L. E. Gilson (Chem. Abstr.).

Alkalosis and Excitability of the Cortical Sensory-motor Centres. (Arch. fisiol., vol. xxxii, p. 361, 1933.) Martino, G., and de'Finis, $L$.

Oral doses of 2-10 grm. of $\mathrm{CaCl}_{\text {, or }} \mathrm{HN}_{4} \mathrm{Cl}$ have no influence on the excitability of the cortical centres of the dog. Pulmonary hyperventilation after doses of these salts does not cause changes, whereas it increases the excitability in non-treated dogs. The latter effect is probably caused by alkalosis.

A. E. Meyer (Chem. Abstr.).

The Barbituric Acids: Their Toxicology. (Thesis, Lille, 1932.) Desodt, C.

The properties, uses, toxicology and colour reactions of five important barbituric acid hypnotics are reviewed. The original work consists in the application of a new method for isolation of barbituric acids from the urine. To $250-300$ c.c. of urine

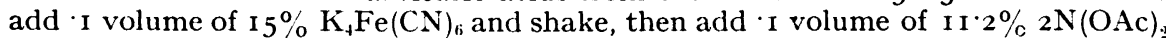
and mix with a stirrer. Filter, and if the filtrate is not acid, add a few drops of $\mathrm{AcOH}$. Transfer to a separating funnel, add 75 c.c. of ether, mix carefully at first, then more vigorously, draw off the aqueous layer and repeat the extraction four times. Dry the combined extracts for 20 minutes with anhydrous sodium sulphate and filter through cotton. Evaporate the ether on a water-bath, extract the residue with 1o-20 c.c. or boiling ethyl alcohol, filter into a weighed dish and evaporate. A white residue is assumed to be pure barbituric acid, and the percentage is calculated from the volumes of urine and of the various filtrates. If the residue is coloured, it is extracted with $20-30$ c.c. of boiling water and treated with animal charcoal for I 5 minutes or until the colour is removed, then evaporated and weighed. The recovery of barbituric acid (barbital, rutonal, gardenal, dial and soneryl) is $89-96 \%$ of the amount present. Essentially the same procedure is said to be applicable to blood, gastric contents and cerebro-spinal fluid. Daily excretion by hospital patients during daily doses for the period indicated averaged : 
Barbital, 25 grm. for $\mathrm{I}_{3}$ days, $65 \%$; rutonal, 2 grm. for $\mathrm{I}_{4}$ days, $49 \%$; dial, - I grm. for 13 days, $30 \%$; gardenal, 2 grm. for 14 days, $25 \%$. The barbituric acids are resistant to putrefaction.

A. W. Dox (Chem. Abstr.).

The Antidotal Action of Picrotoxin, Strychnine and Caffeine in Acute Intoxication by the Barbiturates. (Journ. Pharmacol., vol. xlix, p. 133, 1933.) Maloney, A. $H$.

Picrotoxin is superior to either strychnine or cocaine as an antidote to eleven typical barbiturates.

T. H. Rider (Chem. Abstr.).

The Influence of Barbital on the Activity and Learning of White Rats. (Journ. Comp. Psychol., vol. xvi, p. 317, Dec., 1933.) Omwake, L.

The sodium salt of barbital (veronal) was used, and administration was by intraperitoneal injection-a method which was found to be safe and satisfactory. When barbital was injected in doses of $100 \mathrm{mgrm}$. per kilogramme of body-weight, on alternate days for four months, the activity of the injected rats was slightly lower than that of the controls: there was also a lowering of learning ability. The constant use of barbital over long periods of time and in large doses is relatively safe ; its therapeutic use would never be contra-indicated on the basis of possible chronic physical or mental changes caused thereby.

M. Hamblin Smith.

After-effects of Hypnotics (Barbituric Acid Derivatives). (Arch. Exp. Path. Pharm., vol. clxx, p. 347, 1933.) Mezey, $K$.

The computing efficiency is decreased on the morning after the ingestion of hypnotic doses of allonal, somnifen or dial. Luminal is even more depressant, veronal somewhat less. Veronal and luminal cause increased reaction time and decreased motor performance as after-effects. H. EAGLE (Chem. Abstr.).

Habituation and Cumulation Phenomena. III : The Antagonism of Some Barbituric Acid Derivatives. (Arch. Exp. Path. Pharmacol., vol. clxxii, p. 645, 1933.) Bousmann, M.R.

The administration of phanodorm to dogs prevents the anti-diuretic action of phenobarbital or prominal given later the same day. The anti-diuretic action of tonephin cannot be prevented. The efficacy of hypnotics in preventing antidiuresis varies inversely with the ease of detoxication in vivo.

\section{H. EAgle (Chem. Abstr.).}

Studies on Barbiturates. (Arch. Int. Pharmocodynamie, vol. xlvi, p. 76, 1933.) Koppanyi, T., Murphy, W.S., and Krop, S.

Barbiturates can be determined colorimetrically by adding cobalt acetate and barium hydroxide dissolved in absolute methyl alcohol to a chloroform extract of the unknown. Human beings, cats and dogs excrete in the urine $40-90 \%$ of barbital taken by mouth; fowls excrete approximately $30 \%$. The rate and degree of excretion are not affected by diuretics. The excretion of the other barbiturates (dial, neonal, phenobarbital, pernocton and amytal) is less than that of barbital, decreasing in the order named. The blood concentration of barbital in the first two hours after its administration decreases sharply (fixation by the tissues), followed by a slow decrease (renal excretion). Barbital added to blood in vivo or in vitro is changed to diethyl barbituric acid. The ratio of plasma to erythrocyte concentration is $3: \mathrm{I}$. The brain does not store more barbital than do other organs.

H. EAGLe (Chem. Abstr.).

The Inhibition of Diuresis by Hypnotics. (Arch. Int. Pharmacodynamie, vol. xlvi, p. 97, 1933.) Walton, R. P.

Paraldehyde and sodium phenobarbital inhibit diuresis in dogs. The former is a safe anæsthetic, the latter is unsafe. "Metzrazol" effectively counteracts 